Article

\title{
Soyauxinine, a New Indolopyridoquinazoline Alkaloid from the Stem Bark of Araliopsis soyauxii Engl. (Rutaceae)
}

Cédric Guy Tchatchouang Noulala ${ }^{1,2} \mathbb{D}$, Judith Laure Nantchouang Ouete ${ }^{1}$, Albert Fouda Atangana ${ }^{3}$, Gabin Thierry Bitchagno Mbahbou ${ }^{2,4}$, Ghislain Wabo Fotso ${ }^{1, * \mathbb{D}}$, Hans-Georg Stammler ${ }^{5}$, Bruno Ndjakou Lenta ${ }^{6}$, Emmanuel Ngeufa Happi ${ }^{7, *}$, Norbert Sewald ${ }^{2, *(D)}$ and Bonaventure Tchaleu Ngadjui ${ }^{1}$

Citation: Noulala, C.G.T.; Ouete, J.L.N.; Atangana, A.F.; Mbahbou, G.T.B.; Fotso, G.W.; Stammler, H.-G.; Lenta, B.N.; Happi, E.N.; Sewald, N.; Ngadjui, B.T. Soyauxinine, a New Indolopyridoquinazoline Alkaloid from the Stem Bark of Araliopsis soyauxii Engl. (Rutaceae). Molecules 2022, 27, 1104. https://doi.org/ 10.3390/molecules27031104 Academic Editors: Weishuo Fang Yu Zhang and Ana Estévez-Braun

Received: 27 November 2021

Accepted: 2 February 2022

Published: 7 February 2022

Publisher's Note: MDPI stays neutral with regard to jurisdictional claims in published maps and institutional affiliations.

Copyright: (C) 2022 by the authors. Licensee MDPI, Basel, Switzerland. This article is an open access article distributed under the terms and conditions of the Creative Commons Attribution (CC BY) license (https:// creativecommons.org/licenses/by/ $4.0 /)$.
1 Department of Organic Chemistry, Faculty of Science, University of Yaoundé 1, Yaoundé P.O. Box 812, Cameroon; cedric.noulala@hotmail.fr (C.G.T.N.); ouetejudit@yahoo.fr (J.L.N.O.); ngadjuibt@yahoo.fr (B.T.N.)

2 Organic and Bioorganic Chemistry, Department of Chemistry, Bielefeld University, 33501 Bielefeld, Germany; bmgt198716@gmail.com

3 Department of Chemistry, Faculty of Science, University of Maroua, Maroua P.O. Box 55, Cameroon; atangana_albert@yahoo.fr

4 Department of Chemistry, Faculty of Science, University of Dschang, Dschang P.O. Box 67, Cameroon

5 Department of Chemistry, Inorganic and Structural Chemistry, Bielefeld University, 33501 Bielefeld, Germany; georg.stammler@uni-bielefeld.de

6 Department of Chemistry, Higher Teacher Training College, University of Yaoundé 11 , Yaoundé P.O. Box 47, Cameroon; lentabruno@yahoo.fr

7 Department of Chemistry, Faculty of Science, University of Douala, Douala P.O. Box 24157, Cameroon

* Correspondence: ghis152001@gmail.com (G.W.F.); ngeufa@yahoo.fr (E.N.H.); norbert.sewald@uni-bielefeld.de (N.S.)

\begin{abstract}
The chemical investigation of the total alkaloid extract (TAE) of the stem bark of Araliopsis soyauxii (Rutaceae) afforded an unreported indolopyridoquinazoline (compound 1) along with nine previously known alkaloids 2-10. In addition, six semi-synthetic derivatives 3a-c, 4b, 5a and $\mathbf{6 a}$ were prepared by allylation and acetonidation of soyauxinium nitrate (5), edulinine (3), ribalinine (4) and arborinine (6). The structures and spectroscopic data of five of them are reported herein for the first time. The suggested mechanism for the formation of the new $N$-allylindolopyridoquinazoline 5a is presented. The structures of natural and derived compounds were determined employing extensive NMR and MS techniques. The absolute configuration of stereogenic centers in compounds $2-4$ were determined using NOESY technique and confirmed by the single-crystal X-ray diffraction (SC-XRD) technique. The use of SC-XRD further enabled us to carry out a structural revision of soyauxinium chloride recently isolated from the same plant to soyauxinium nitrate (5). The TAE, fractions, compounds 1-7 and 9, and semi-synthetic derivatives $\mathbf{3 a}-\mathbf{c}, \mathbf{4 b}, \mathbf{5} \mathbf{a}$ and $\mathbf{6} \mathbf{a}$ were evaluated for their cytotoxic activity towards the cervix carcinoma cell line KB-3-1. No significant activity was recorded for most of the compounds except for 9, which showed moderate activity against the tested cancer cell lines.
\end{abstract}

Keywords: Araliopsis soyauxii; Rutaceae; alkaloids; soyauxinine; cytotoxic activity

\section{Introduction}

Araliopsis soyauxii Engl. [syn.Vepris soyauxii (Engl.) Mziray] (Rutaceae) is a rich source of new bioactive substances. Our previous reports provided valuable insights on the biology and chemistry of the studied plant, which contains different types of alkaloids, including quinazoline, furoquinoline, indolopyridoquinazoline, and oxazole [1-3] examples, as almost every other species of the genus Araliopsis does. Furoquinolinelike alkaloids form the most representative class of compounds, with more than twenty derivatives already isolated in the genus and five encountered in the studied species. These compounds are reputed for their cytotoxicity. They include 5-methoxymaculine, 5,8dimethoxymaculine, 4,5,6,7,8-pentamethoxyfuroquinoline, skimmianine, flindersiamine, 
maculine and kokusaginine, which showed potent activity against the A2780 cell line with $\mathrm{IC}_{50}$ values ranging from 2.0 to $4.0 \mu \mathrm{M}$ [4,5]. Their antibacterial and antioxidant activities were also reported [6,7]. However, none of the authors have applied a well-known total alkaloid extraction procedure to the crude plant extract before any isolation and purification of the alkaloids.

\section{Results and Discussion}

Herein we report the isolation and structural characterization of ten natural compounds from the total alkaloid extract of $A$. soyauxii, including a new indolopyridoquinazoline and the structural revision of soyauxinium chloride [1,2]. Furthermore, six semisynthetic alkaloid derivatives were prepared. The crude extracts, fractions, isolated compounds, and the semi-synthetic alkaloid derivatives were investigated for their cytotoxic activity against the cervix carcinoma cell line KB-3-1.

The total alkaloid extract of $A$. soyauxii was subjected to open silica gel column chromatography and on a normal-phase medium pressure liquid chromatography (NP-MPLC), affording ten compounds 1-10, including the new indolopyridoquinazoline-type alkaloid $\mathbf{1}$ (Figure 1). Six semi-synthetic derivatives (compounds $\mathbf{3 a}-\mathbf{c}, \mathbf{4} \mathbf{b}, \mathbf{5} \mathbf{a}$ and $\mathbf{6 a}$ ) were prepared by allylation and acetonidation of some of the isolates. The isolated alkaloids and synthetic derivatives structures were determined by extensive interpretation of the NMR, MS, and SC-XRD data.
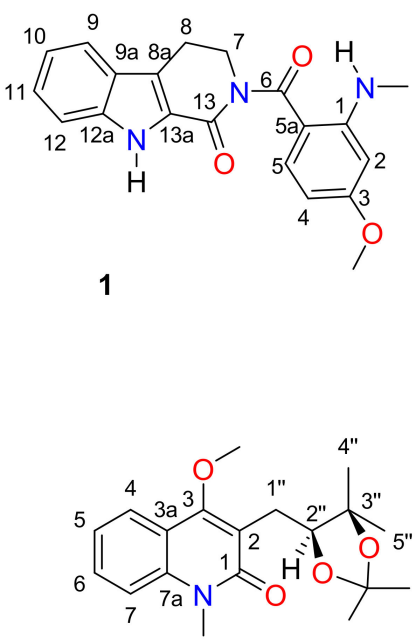

$3 b$<smiles></smiles>

5<smiles>CNc1ccccc1C(=O)N1CCc2c([nH]c3ccccc23)C1=O</smiles>

8<smiles>COc1ccc2c3c(c(=O)n(C)c2c1OC)[C@@H](O)[C@H](O)C(C)(C)O3</smiles>

2<smiles>Cn1c(=O)c2c(c3ccccc31)OC(C)(C)C=C2</smiles>

3c

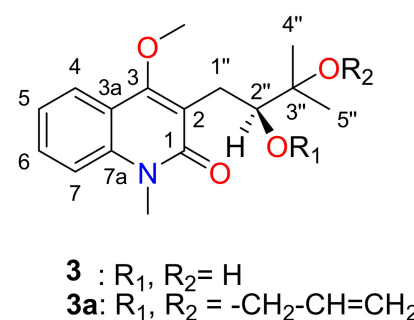<smiles>[R9]O[C@H]1Cc2c(n(C)c3ccccc3c2=O)OC1([2H])[3H]</smiles>

4: $\mathrm{R}_{3}=\mathrm{H}$

4b: $\mathrm{R}_{3}=-\mathrm{CH}_{2}-\mathrm{CH}=\mathrm{CH}_{2}$

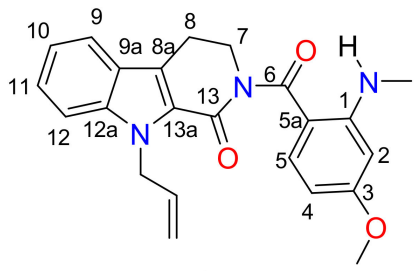

$5 a$<smiles>[R20]c1c(OC)c(OC)cc2c1c(=O)c1ccccc1n2C</smiles>

6a: $\mathrm{R}_{4}=-\mathrm{CH}_{2}-\mathrm{CH}=\mathrm{CH}_{2}$<smiles>COc1c2c(cc3c(OC)c4c(cc13)OCO4)OCO2</smiles>

7<smiles>COc1cc(=O)n(C)c2ccccc12</smiles>

10

Figure 1. Chemical structures of compounds 1-10. 


\subsection{Structural Identification of Compounds}

Compound 1 was isolated as yellow needles soluble in $\mathrm{CDCl}_{3}$. Its molecular formula $\mathrm{C}_{20} \mathrm{H}_{19} \mathrm{~N}_{3} \mathrm{O}_{3}$ was deduced from its HRESIMS (Figure S1), which showed the sodium adduct ion peak at $m / z 372.1313$ (calcd. $m / z 372.1318$ for $\mathrm{C}_{20} \mathrm{H}_{19} \mathrm{~N}_{3} \mathrm{O}_{3} \mathrm{Na}$ ). The ${ }^{1} \mathrm{H}-\mathrm{NMR}$ spectrum (Figure S2, Table 1) of compound 1 exhibited an exchangeable signal at $\delta_{H} 9.69(1 \mathrm{H}$, brs, $\mathrm{NH})$, two triplets at $\delta 4.15(\mathrm{~J}=6.4 \mathrm{~Hz})$ and $3.20(\mathrm{~J}=6.4 \mathrm{~Hz})$, respectively characteristic of the C-7 and C-8 methylene protons of an indoloquinazoline alkaloid [1]. Several ${ }^{13}$ C-NMR and ${ }^{1} \mathrm{H}-\mathrm{NMR}$ resonances (Figures S2-S4) were ascribed to the indole moiety including those of an ortho-disubstituted aromatic ring at $\delta_{H} / \delta_{C} 7.63(\mathrm{~d}, J=8.0 \mathrm{~Hz}, \mathrm{H}-9) / 120.7 ; 7.16(\mathrm{t}$, $J=8.0 \mathrm{~Hz}, \mathrm{H}-10) / 120.7 ; 7.28(\mathrm{t}, J=8.0 \mathrm{~Hz}, \mathrm{H}-11) / 126.0$ and $7.14(\mathrm{t}, J=8.0 \mathrm{~Hz}, \mathrm{H}-12) / 113.0$. The quaternary carbons were found at $\delta c 122.3(\mathrm{C}-8 \mathrm{a}), 125.0(\mathrm{C}-9 \mathrm{a}), 138.4(\mathrm{C}-12 \mathrm{a})$ and 126.4 (C-13a) [1]. Two aliphatic methylene groups resonated at $\delta_{H} / \delta_{C} 4.15(\mathrm{t}, J=6.4 \mathrm{~Hz}, \mathrm{H}-7) / 47.8$ and $3.20(t, J=6.4 \mathrm{~Hz}, \mathrm{H}-8) / 21.3$. These were assigned to a six-membered ring with a carbamide group at $\delta \mathrm{c} 162.1$ (C-13) ortho-fused to the indole moiety [1]. The fused rings were confirmed by HMBC interactions of H-7 $\left(\delta_{H} 4.15\right), \mathrm{H}-8\left(\delta_{H} 3.20\right), \mathrm{H}-10\left(\delta_{H} 7.16\right)$ and $\mathrm{H}-11\left(\delta_{H} 7.28\right)$ to carbons C-8a $(\delta c 122.3), \mathrm{C}-13 \mathrm{a}(\delta c 126.4), \mathrm{C}-9 \mathrm{a}(\delta c 125.0)$ and C-11( $\left.\delta c 126.0\right)$ (Figure 2).

Table 1. ${ }^{1} \mathrm{H}-\mathrm{NMR}$ data $\left(600 \mathrm{MHz}, \mathrm{CDCl}_{3}\right)$ and ${ }^{13} \mathrm{C}-\mathrm{NMR}$ data $\left(150 \mathrm{MHz}, \mathrm{CDCl}_{3}\right)$ of soyauxinine (1).

\begin{tabular}{|c|c|c|c|}
\hline \multirow{2}{*}{ Position } & \multicolumn{2}{|c|}{1} & \multirow[b]{2}{*}{ НМВС } \\
\hline & $\delta \mathrm{c}$ & $\delta_{\mathbf{H}}$ & \\
\hline 1 & 154.0 & & \\
\hline 2 & 94.8 & $6.18(1 \mathrm{H}, \mathrm{d}, J=2.4)$ & 1,3 \\
\hline 3 & 165.4 & & \\
\hline 4 & 102.2 & $6.11(1 \mathrm{H}, \mathrm{dd} ; J=9.0,2.4)$ & $3,5 a$ \\
\hline 5 & 135.5 & $7.45(1 \mathrm{H}, \mathrm{d}, J=9.0)$ & $1,3,6$ \\
\hline $5 a$ & 109.0 & & \\
\hline 6 & 175.1 & & \\
\hline 7 & 47.8 & $4.15(2 \mathrm{H}, \mathrm{t}, J=6.4)$ & $6,8 \mathrm{a}, 13$ \\
\hline 8 & 21.3 & $3.20(2 \mathrm{H}, \mathrm{t}, J=6.4)$ & $8 a, 13 a$ \\
\hline $8 a$ & 122.3 & & \\
\hline $9 a$ & 125.0 & & \\
\hline 9 & 120.7 & $7.63(1 \mathrm{H}, \mathrm{d}, J=8.0)$ & $12,12 \mathrm{a}$ \\
\hline 10 & 120.7 & $7.16(1 \mathrm{H}, \mathrm{t}, J=8.0)$ & $9 a, 12$ \\
\hline 11 & 126.0 & $7.28(1 \mathrm{H}, \mathrm{t}, J=8.0)$ & $9,10,12$ \\
\hline 12 & 113.0 & $7.14(1 \mathrm{H}, \mathrm{t}, J=8.0)$ & $9,9 a, 10$ \\
\hline $12 a$ & 138.4 & & \\
\hline $13 a$ & 126.4 & & \\
\hline 13 & 162.1 & & \\
\hline $1-\mathrm{NCH}_{3}$ & 29.7 & $2.96(3 \mathrm{H}, \mathrm{d}, J=5.0)$ & 1 \\
\hline $1-\mathrm{NHCH}_{3}$ & & $7.80(1 \mathrm{H}, \mathrm{q}, J=5.0)$ & 2 \\
\hline $3-\mathrm{OCH}_{3}$ & 55.3 & $3.81(1 \mathrm{H}, \mathrm{s})$ & 3 \\
\hline NH & & 9.69 , brs & $8 a, 12 a$ \\
\hline
\end{tabular}

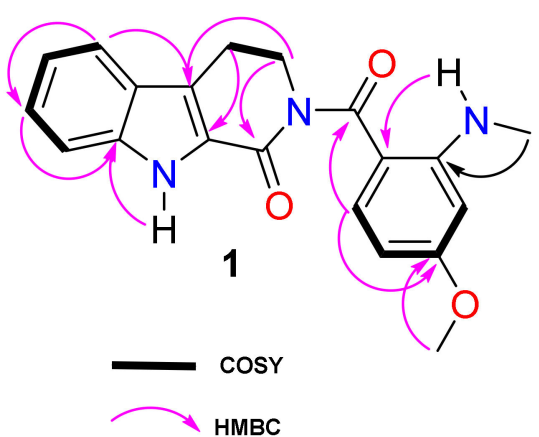

Figure 2. COSY and key HMBC correlations of compound 1. 
The NMR spectra (Figures S2-S6) also showed resonances of another exchangeable proton of an amine at $7.80(1 \mathrm{H}, \mathrm{q}, J=5.0 \mathrm{~Hz})$ linked to an aminomethyl group at $\delta_{\mathrm{H}} / \delta_{\mathrm{C}}$ $2.96\left(3 \mathrm{H}, \mathrm{d}, J=5.0 \mathrm{~Hz}, \mathrm{NH}-\mathrm{C}_{3}\right) / 29.7$. An $\mathrm{ABX}$ system of a trisubstituted aromatic ring was observed at $\delta_{H} / \delta_{C} 6.18(1 \mathrm{H}, \mathrm{d}, J=2.4 \mathrm{~Hz}, \mathrm{H}-2) / 94.8 ; 6.11(1 \mathrm{H}, \mathrm{dd}, J=9.0,2.4 \mathrm{~Hz}$, $\mathrm{H}-4) / 102.2$ and $7.45(1 \mathrm{H}, \mathrm{d}, J=9.0 \mathrm{~Hz}, \mathrm{H}-5) / 135.5$. The spectra also displayed signals of a methoxy group at $\delta_{H} / \delta_{C} 3.81(3 \mathrm{H}, \mathrm{s}) / 55.3$, which was located on the trisubstituted aromatic ring based on the HMBC correlation (Figure 2) between the methoxy proton at $\delta_{H} 3.81$ and $\mathrm{C}-3\left(\delta_{\mathrm{C}} 165.4\right)$. Both moieties of the tri-fused rings and the trisubstituted aromatic were linked through a second carbamide at $\delta \mathrm{c} 175.1(\mathrm{C}-6)$ as confirmed by the long-range interaction $\left({ }^{3} J\right.$ ) of $\mathrm{H}-5$ and $\mathrm{H}-7$ to the carbamide $\mathrm{C}-6$ on HMBC spectrum (Figure S7).

Therefore, the structure of $\mathbf{1}$ was unambiguously determined as a methoxylated derivative of rhetsinine (8), an indolopyridoquinazoline-like alkaloid also reported in this study. To fully characterize compound $\mathbf{1}$, it was subjected to SC-XRD analysis.

Other compounds were identified as: edulinine (3), arborinine (6), flindersiamine (7), rhetsinine (8), maculine (9), 4-methoxy-1-methyl-2(1H)-quinolinone (10) and $\mathrm{N}$-methylflindersine (3c) $[1,6,8]$. Their structures were determined by comparing their NMR data with those reported in the literature.

\subsection{SC-XRD Analyses}

Suitable crystals of $\mathbf{1}$, obtained by recrystallization by slow evaporation from dichloro methane, were applied to SC-XRD. The crystal structure is shown in Figure 3. Indeed, the phenyl unit is rotated $62.3(1)^{\circ}$ from the indole unit, as a result building a hydrogen bond between the bridged carbonyl and the methylamine proton. In that stable conformation, the $\mathrm{N}-\mathrm{H} \cdots$ O angle is $134(3)^{\circ}$, and the $\mathrm{N} \cdots$ O distance is $2.80(1) \AA$. This interaction could also explain the downfield resonance of the amine proton $\mathrm{NHCH}_{3}$ at $\mathrm{C}-1$. The peri-labile proton of the indole moiety and the carbonyl group are involved in an intermolecular interaction that forms hydrogen-bonded dimers (Figure 3, 1dimer). Thus, compound 1 was fully characterized as 3-methoxyrhetsinine, an unreported indolopyridoquinazoline alkaloid to which the trivial name soyauxinine was proposed.

The crystal structure of racemic ( \pm )-araliopsinine (2) reveals the opposite chirality of the two neighbouring asymmetric carbon atoms. It crystallizes as a racemate in the space group $P 2_{1} / c$. Optically pure (S)-edulinine (3) crystallizes in space group C2. The asymmetric unit contains two molecules of edulinine, and both show the chirality of $S$ at the asymmetric carbon atom. One of these two molecules shows a positional disorder of the methyl diol unit with a ratio 57:43. This disorder contains the asymmetric carbon atom, but both disordered atoms show the chirality of $S$. The chirality is confirmed by a Flack parameter which refines to 0.06(6). In Figure 3, only the non-disordered molecule is shown. (S)-Ribalinine (4) crystallizes in the space group $P 2{ }_{1} 2_{1} 2_{1}$. Its stereochemistry $S$ was confirmed with a Flack parameter of 0.00(7). Additionally, ribalinine could be obtained as a racemate (4a) in the centrosymmetric space group $P 2_{1} / n$.

In Figure 3, only the asymmetric carbon atoms are labelled. Compounds $\mathbf{2}$ and $\mathbf{4 a}$ are racemic mixtures, the shown enantiomers in this figure are arbitrary due to centrosymmetric space groups.

We recently published a contribution to the taxonomy and chemistry of A. soyauxii. We reported the isolation of a new mesomeric form of quaternary indoloquinazoline alkaloid named soyauxinium chloride [1,2]. At that time, neither the NMR nor the MS data (Supplementary Materials) were enough to finalize the structure. Nevertheless, we tentatively assigned chloride as the counter ion of our compound because of previous pieces of evidence in the literature $[9,10]$. However, compound 5 turned out to be soyauxinium nitrate as it crystallizes in the space group $P 2_{1} / \mathcal{c}$ (Figure 3 ). Therefore, the previously published soyauxinium chloride structure (Figures S28-S35) [1,2] should be revised to soyauxinium nitrate (5). The presence of nitrate as counter-ion is not surprising as nitrate ions $\left(\mathrm{NO}_{3}{ }^{-}\right)$are assimilated by plants from the soil for nutritional, environmental, or physiological purposes [11]. 


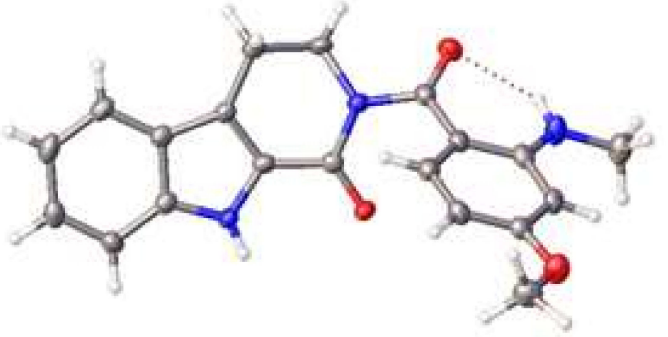

1

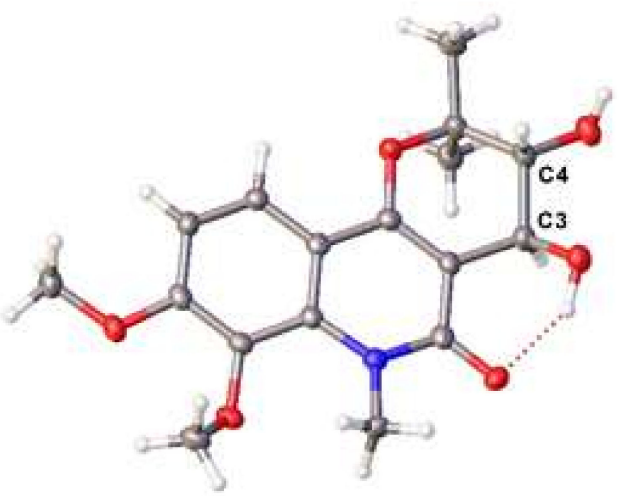

2

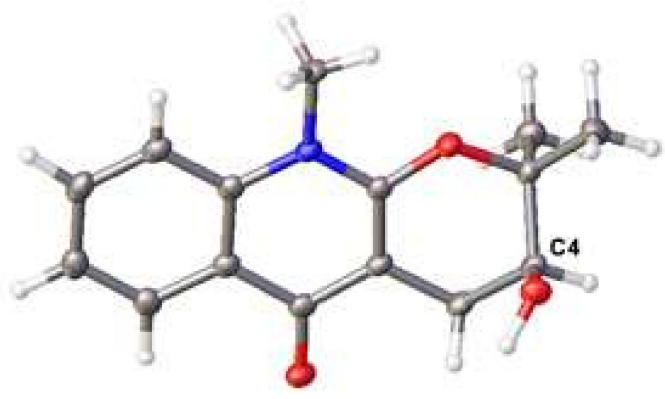

4

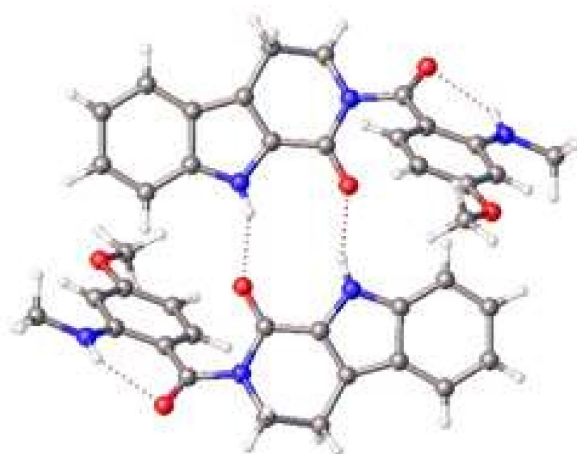

1 dimer

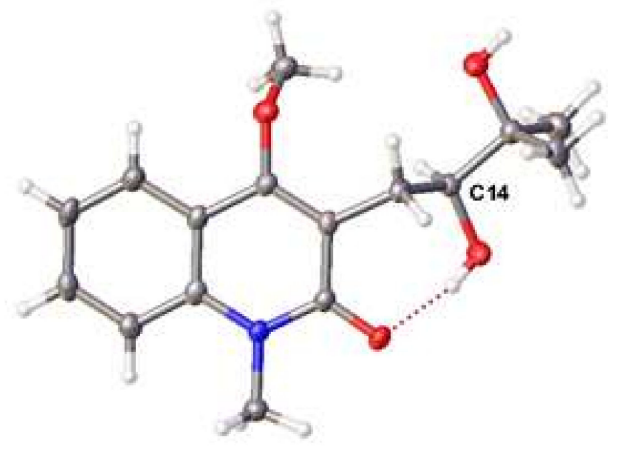

3

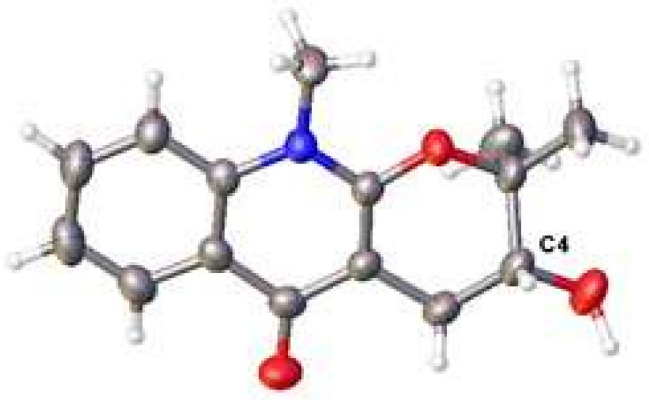

$4 a$

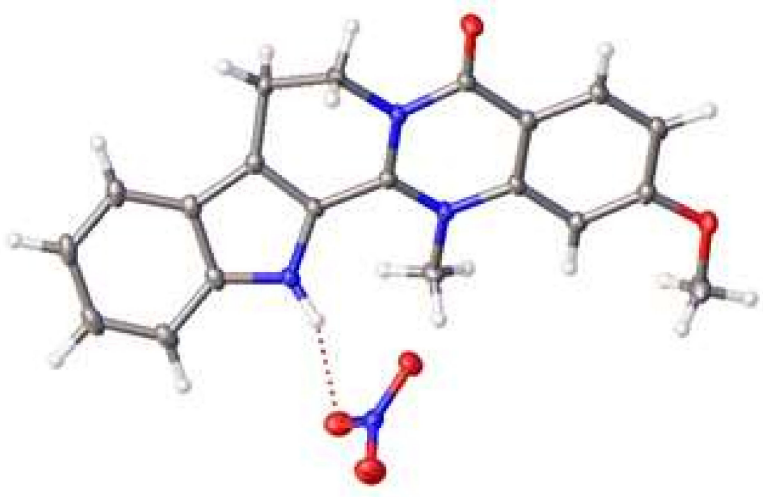

Figure 3. Molecular structures of the crystals of $\mathbf{1 - 4}, \mathbf{4 a}$ and $\mathbf{5}$ in ORTEP style at $50 \%$ probability level. 


\subsection{Semi-Synthesis of Allylated and Acetonitaded Derivatives of Some Naturally Isolated Alkaloids}

Barron and co-workers observed that the addition of hydrophobic groups increases the lipophilicity of molecules, therefore enhancing the cytotoxicity activity [12]. Based on this observation, allylation and acetonidation reactions were performed on soyauxinium nitrate (5), edulinine (3), ribalinine (4) and aborinine (6) which led to six semi-synthetic derivatives, among which five (compounds $\mathbf{3 a}, \mathbf{3} \mathbf{b}, \mathbf{4} \mathbf{b}, \mathbf{5} \mathbf{a}$ and $\mathbf{6 a}$ ) are reported here for the first time (Scheme 1).<smiles>COc1c(CC(O)C(C)(C)O)c(=O)n(C)c2ccccc12</smiles>

3

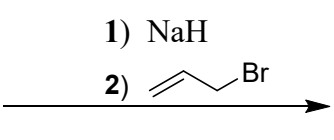

DMF, rt, 16 h<smiles>C=CCOC(Cc1c(OC)c2ccccc2n(C)c1=O)C(C)(C)OCC=C</smiles>

2', 3'-diallyledulinine (3a) $14 \%$<smiles>Cn1c(=O)c2c(c3ccccc31)OC(C)(C)C=C2</smiles>

$\mathrm{N}$-methylflindersine (3c) $13 \%$<smiles>COc1c(CC(O)C(C)(C)O)c(=O)n(C)c2ccccc12</smiles>

3<smiles>Cn1c2c(c(=O)c3ccccc31)CC(O)C(C)(C)O2</smiles>

4<smiles>C=CCOC1Cc2c(n([14CH3])c3ccccc3c2=O)OC1(C)C(C)(C)C</smiles><smiles>COC1=CC=c2cc([N+](=O)[O-])c3n(c2=O)N1CCc1[nH]c2ccccc2c1[N+]=3[O-]</smiles>

5<smiles>COc1cc2c(c(O)c1OC)c(=O)c1ccccc1n2C</smiles>

6<smiles>COc1c(CC2OC(C)(C)OC2(C)C)c(=O)n(C)c2ccccc12</smiles>

Edulinine 2', 3'-acetonide (3b) $34 \%$<smiles>C=CCn1c2c(c3ccccc31)CCN(C(=O)c1ccc(OC)cc1NC)C2=O</smiles>

$N$-allylsoyauxinine (5a) $52 \%$

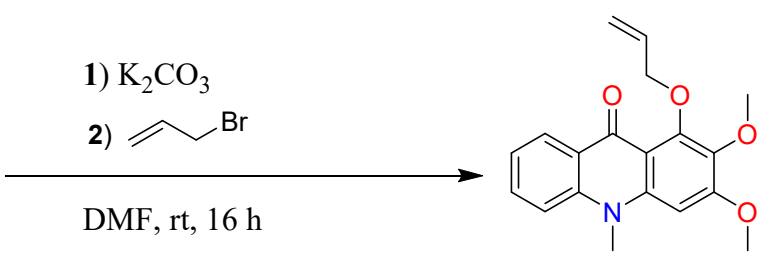

1-allylarborinine (6a) $37 \%$

Scheme 1. Semi-synthesis of 3a-6a by allylation or acetonidation reactions of 1, 3, 4 and 6 .

$2^{\prime}, 3^{\prime}$-Diallyledulinine (3a, 2.4mg, 14\%) (Figures S8-S12) and N-methylflindersine (3c, $2.1 \mathrm{mg}, 13 \%$ ) (Figures S16-S18) were prepared from the reaction between edulinine (3) and allyl bromide with sodium hydride as base. They were obtained as yellowish oils isolated by preparative TLC of the dried mixture eluting with petroleum ether/EtOAc (70:30). 
The formation of $3 c$ can be explained by the following mechanism of a nucleophilic substitution on an unsaturated carbon favoured by the presence of a carbonyl group, as shown in Scheme 2.

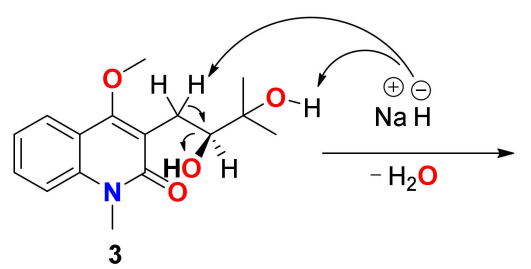<smiles>COc1c(/C=C/C(C)(C)O[Na])c(=O)n(C)c2ccccc12</smiles><smiles>C=CCn1c(=O)c2c(OC)cccc2c2ccccc21</smiles><smiles>Cn1c(=O)c2c(c3ccccc31)C(C)(C)C=C2</smiles><smiles>CO[N+](C)([O-])O[Na]</smiles><smiles>COC12OC(C)(C)C=CC1(OC)N(C)c1ccccc12</smiles>

$3 c$

Scheme 2. Proposed mechanism for the formation of compound 3c.

Edulinine-2' $3^{\prime}$-acetonide (3b, $10.2 \mathrm{mg}, 34 \%$ ) (Figures S13-S15) was prepared from edulinine (3) and $p$-toluene sulfonic acid and obtained as white needles.

Reactions between ribalinine (4) and sodium hydride with allyl bromide as reagent gave 2-allylribalinine $(4 \mathrm{~b}, 6.2 \mathrm{mg}, 55 \%)$ as a yellow oil (Figures S19-S21) while arborinine (6) and potassium carbonate afforded semisynthetic 1-allylarborinine (6a, $1.1 \mathrm{mg}, 37 \%)$ also obtained as a yellow oil (Figures S25-S27).

The same protocol when applied to soyauxinium nitrate (5) afforded $N$-allylsoyauxinine (5a, $10.2 \mathrm{mg}, 52 \%$ ) (Figures S22-S24). The mechanism for the formation of compound 5a is shown in Scheme 3.

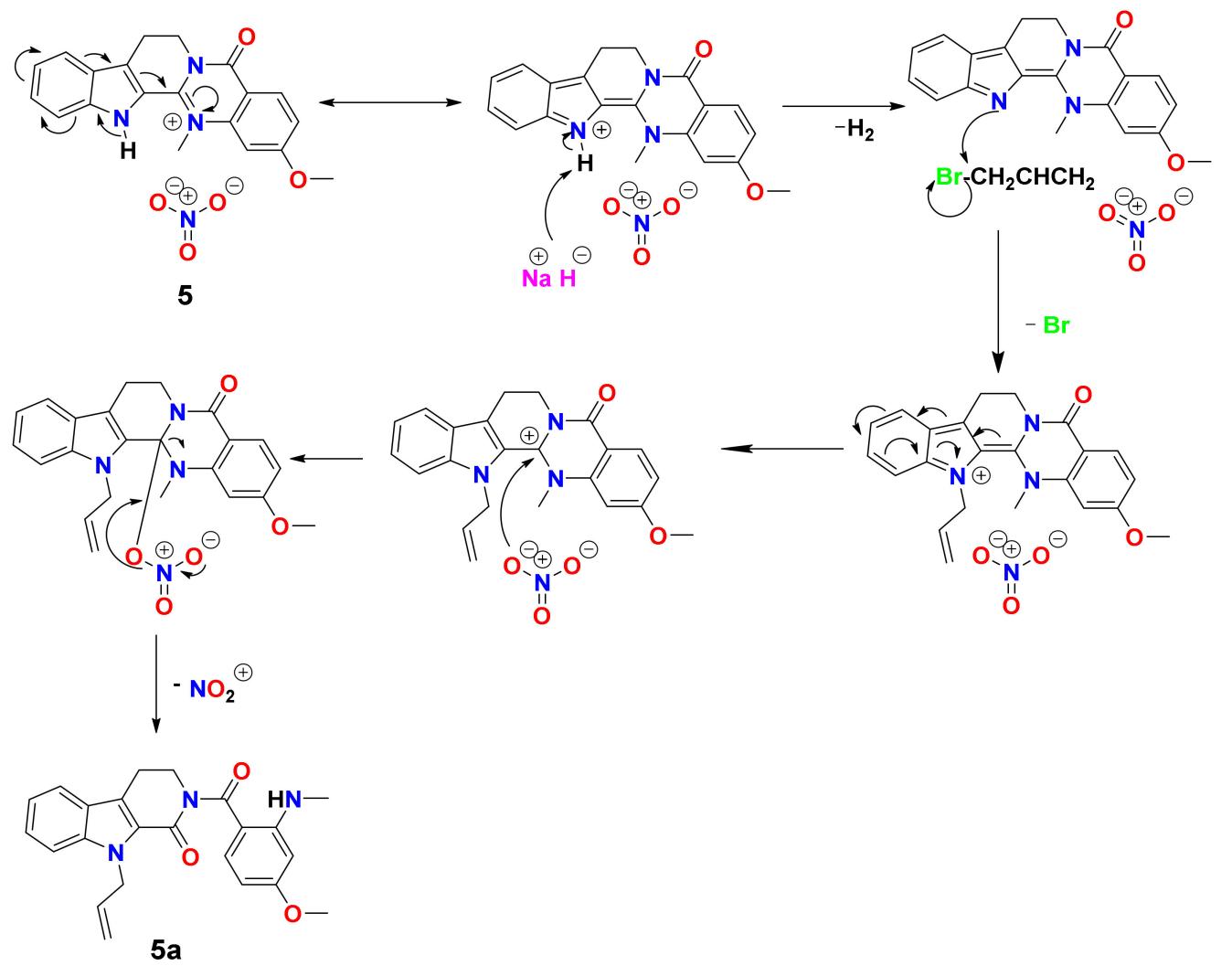

Scheme 3. Proposed mechanism for the formation of compound 5a. 


\subsection{Cytotoxic Activity of the Extract, Fractions, and Isolated Compounds}

The total alkaloid extract of the stem bark of $A$. soyauxii (TAE), fractions obtained from TAE (FTAE1-FTAE3), natural compounds 1-7 and 9, and semi-synthetic derivatives $\mathbf{3 a}-\mathbf{c}, \mathbf{4 b}, \mathbf{5 a}, \mathbf{6} \mathbf{a}$ were evaluated for their anticancer properties against the cervix carcinoma cell line (KB-3-1) as described in previous reports [13-16]. Extracts and fractions were inactive. Maculine (9) showed moderate cytotoxic activity against KB-3-1 with $\mathrm{IC}_{50}$ of $10 \mu \mathrm{M}$ compared to griseofulvin $\left(\mathrm{IC}_{50}=17-21 \mu \mathrm{M}\right)$, used as a reference drug. Other compounds were found inactive against the same cancer cell line. Arborinine (6) has been previously proven to exhibit toxicity against HeLa, MCF-7, and A431 cancer cell lines with $\mathrm{IC}_{50}$ values of $1.84,11.74$, and $12.95 \mu \mathrm{M}$, respectively [16]. Likewise, maculine (9) was also found to display moderate cytotoxic activity $\left(\mathrm{IC}_{50}=100 \mu \mathrm{M}\right)$ against the colorectal HT-29 adenocarcinoma cells [1]. The difference in efficacy of these compounds could be related to the sensitivity of cancer cells towards each compound. Maculine is known to be more harmful to cervical tumour than colorectal cells, while arborinine presents a similar response towards epidermal and breast cancer cells. However, compound 6 was active against cervical cancer cells HeLa but inactive towards KB-3-1 cells [17]. As a result, the semi-synthetic derivatives, $N$-allylsoyauxinine (5a) and 1-allylarborinine (6a), were transparent compared to soyauxinium nitrate (5) arborinine (6), suggesting that the moderate response of compounds 5 and $\mathbf{6}$ might be related to their labile heteroatom protons. Semi-synthetic compounds $2^{\prime}, 3^{\prime}$-diallyledulinine (3a), $N$-methylflindersine (3c), edulinine-2' ${ }^{\prime} 3^{\prime}$-acetonide ( $\left.3 \mathbf{b}\right)$, 2-allylribalinine ( $4 \mathbf{b}$ ) and compounds edulinine (3), ribalinine (4) were also inactive against the KB-3-1 cancer cells. The obtained results indicate that the increase of lipophilicity of the studied alkaloids by the addition of hydrophobic groups is not enough to enhance their cytotoxicity activity. Results are shown in Table 2.

Table 2. $\mathrm{IC}_{50}(\mu \mathrm{M})$ values of cytotoxic activity of the extract, fractions, isolates, and semi-synthetic derivatives.

\begin{tabular}{cc}
\hline & IC $_{\mathbf{5 0}}(\boldsymbol{\mu M})$ \\
\hline Samples & KB-3-1 \\
\hline $\mathbf{1}$ & $>50$ \\
$\mathbf{2}$ & Inactive \\
$\mathbf{3}$ & Inactive \\
$\mathbf{3 a}$ & Inactive \\
$3 \mathbf{b}$ & $>500$ \\
$3 \mathbf{c}$ & $>500$ \\
$\mathbf{4}$ & Inactive \\
$\mathbf{4 b}$ & Inactive \\
$\mathbf{5}$ & Inactive \\
$\mathbf{5 a}$ & Inactive \\
$\mathbf{6}$ & 50 \\
$\mathbf{6 a}$ & $>500$ \\
7 & Inactive \\
$\mathbf{9}$ & 10 \\
FTAE1 & Inactive \\
FTAE2 & Inactive \\
FTAE3 & Inactive \\
TAE & Inactive \\
Griseofulvin & $17-21$ \\
\hline
\end{tabular}

TAE: Total alkaloid extract; FTAE1: Fraction 1 of total alkaloid extract; FTAE2: Fraction 2 of total alkaloid extract FTAE3: Fraction 3 of total alkaloid extract

\section{Materials and Methods}

\subsection{General Information}

Electrospray ionization (ESI) mass spectra were recorded on a 1200-series HPLCsystem or a 1260-series Infinity II HPLC-system (Agilent Technologies, Santa Clara, CA, USA) with binary pump and integrated diode array detector coupled to an LC/MSDTrap-XTC-mass spectrometer (Agilent Technologies) or an LC/MSD Infinity lab LC/MSD 
(G6125B LC/MSD). High-resolution mass spectra were recorded on a Micromass-Q-TOFUltima-3-mass spectrometer (Waters, Milford, MA, USA) with Lock Spray-interface and a suitable external calibrant. UV-Vis spectra were recorded on an Evolution 201 UV-Visible Spectrophotometer (Thermo Scientific, Waltham, MA, USA) and infrared (IR) spectra on a Tensor 27 FTIR-spectrometer (Bruker, Billerica, MA, USA) equipped with a diamond ATR unit and are reported in terms of frequency of absorption in $\mathrm{cm}^{-1}$. The NMR spectra were recorded on a Bruker Avance III $500 \mathrm{HD}\left({ }^{1} \mathrm{H}: 500 \mathrm{MHz},{ }^{13} \mathrm{C}: 126 \mathrm{MHz}\right)$ or Avance $600\left({ }^{1} \mathrm{H}\right.$ : $600 \mathrm{MHz},{ }^{13} \mathrm{C}: 151 \mathrm{MHz}$ ) spectrometer. Chemical shifts $\delta$ (ppm) are reported relative to residual solvent signal and/or tetramethylsilane (TMS). 2D spectra (COSY, HMQC, HMBC) and DEPT-135 spectra were used for signal assignment. The NMR spectra were recorded on a Bruker Avance-III ( ${ }^{1} \mathrm{H}-\mathrm{NMR}: 600 \mathrm{MHz}$ and ${ }^{13} \mathrm{C}-\mathrm{NMR}$ : $\left.151.1 \mathrm{MHz}\right)$ spectrometer. Column chromatography was carried out on silica gel 230-400 mesh and silica gel 70-230 mesh (Merck, Darmstadt, Germany). Automated column chromatography was also performed on a Reveleris ${ }^{\circledR}$ X2 system (Büchi, Flawil, Switzerland) equipped with a binary pump and ELSD detector using a flash up column of $4 \mathrm{~g}, 12 \mathrm{~g}$, and $24 \mathrm{~g}$, depending on the sample mass or a Snap Ultra C18 column (Biotage, Uppsala, Sweden) with a gradient at various flow rate. Thin-layer chromatography (TLC) was performed on Merck precoated silica gel $60 \mathrm{~F}_{254}$ aluminum foil and was revealed using a UV lamp $(254-365 \mathrm{~nm})$ and $10 \% \mathrm{H}_{2} \mathrm{SO}_{4}$ reagent followed by heating.

\subsection{Plant Material}

The stem bark of A. soyauxii Engl. was collected at UNALOR, Kumba, South-West Region of Cameroon in January 2016. The plant material was identified by the botanist Mr. NANA Victor of the Cameroon National Herbarium where a voucher specimen (Ref. 38959 HNC) has been deposited.

\subsection{Extraction and Isolation}

The stem bark crude extract of $A$. soyauxii (125.7 g) was dissolved in a sulfuric acid solution ( $\mathrm{c}=2 \mathrm{M}$ ). The acidified extract was then washed with EtOAc to afford the aqueous and organic layers, which were separated. An ammonia solution was used to basify the aqueous layer to obtain an organic solution with a $\mathrm{pH}$ value of 12 . The organic solution containing alkaloids was washed with DCM to afford the total alkaloid extract (10.5 g). A portion of the total alkaloid extract (TAE) (10.3 g) was fractionated on a silica gel column eluted with a stepwise gradient of $\mathrm{CH}_{2} \mathrm{Cl}_{2}-\mathrm{MeOH}$ mixtures of increasing polarity then with $\mathrm{MeOH}$. A total of 50 fractions (ca. $100 \mathrm{~mL}$ each) were collected as follows: $\mathrm{CH}_{2} \mathrm{Cl}_{2}(1-4)$, $\mathrm{CH}_{2} \mathrm{Cl}_{2} / \mathrm{MeOH} 5 \%$ (5-12), $\mathrm{CH}_{2} \mathrm{Cl}_{2} / \mathrm{MeOH} 10 \%$ (13-20), $\mathrm{CH}_{2} \mathrm{Cl}_{2} / \mathrm{MeOH} 20 \%$ (21-29), $\mathrm{CH}_{2} \mathrm{Cl}_{2} / \mathrm{MeOH} 30 \%$ (30-37), $\mathrm{CH}_{2} \mathrm{Cl}_{2} / \mathrm{MeOH} 50 \%$ (38-46) and $\mathrm{CH}_{2} \mathrm{Cl}_{2} / \mathrm{MeOH} 70 \%$ (47-50). Three main fractions FTAE1 (1-21, $1.5 \mathrm{~g})$; FTAE2 (22-32, $5.7 \mathrm{~g})$, and FTAE3 (33-50, $1.7 \mathrm{~g}$ ), were obtained based on their TLC profiles. Part of fraction FTAE1 (1.4 g) was further fractionated on a normal-phase medium pressure liquid chromatography (NP-MPLC) with a stepwise gradient of EtOAc-MeOH mixtures to afford 60 sub-fractions of $18 \mathrm{~mL}$ each. Based on their analytical TLC profiles, they were combined into five major fractions labelled FTAE1A (1-15, $250.8 \mathrm{mg})$, FTAE1B (16-26, $400.5 \mathrm{mg})$, FTAE1C (27-40, $350.3 \mathrm{mg})$, and FTAE1D (41-60, $120.4 \mathrm{mg})$. Maculine $(9 ; 3.5 \mathrm{mg}$ ) and 4-methoxy-1-methyl-2(1H)quinolinone $(10 ; 2.6 \mathrm{mg})$ were obtained from the purification of fraction FTAE1B over a silica gel column with isocratic $n$-hexane-EtOAc $20 \%$. Fraction FTAE1C was subjected to column chromatography using silica gel column with $n$-hexane-EtOAc $30 \%$ to afford flindersiamine $(7 ; 2.8 \mathrm{mg})$, while $S$-edulinine $(3 ; 72.6 \mathrm{mg})$ and $(4 S)$-ribalinine $(4 ; 15.6 \mathrm{mg})$ were obtained from the purification of fraction FTAE1D with $n$-hexane-EtOAc $40 \%$ and $n$-hexane-EtOAc $45 \%$ respectively. Part of fraction FTAE2 (5.0 g) was further fractionated on NP-MPLC with a stepwise gradient of EtOAc-MeOH mixtures to afford 40 sub-fractions of $18 \mathrm{~mL}$ each. Based on their analytical TLC profiles, these sub-fractions were grouped into three major fractions labelled FTAE2A (1-12, 1.2 g), FTAE2B (13-25, $1.5 \mathrm{~g})$, and FTAE2C $(26-40,1.1 \mathrm{~g})$. Further purification of fractions FTAE2B and FTAE2C gave arborinine 
$(6 ; 3.2 \mathrm{mg})$ and $(+) /(-)$-araliopsinine $(2 ; 5.2 \mathrm{mg})$ at $n$-hexane-EtOAc $25 \%$ and $n$-hexaneEtOAc 35\% respectively. Part of fraction FTAE3 $(1.6 \mathrm{~g})$ was also flashed on NP-MPLC with a stepwise gradient of $\mathrm{CH}_{2} \mathrm{Cl}_{2}-\mathrm{MeOH}$ mixtures to afford 30 sub-fractions of $18 \mathrm{~mL}$ each. Based on their analytical TLC profiles, these sub-fractions were combined into two major fractions labelled FTAE3A (1-19, 800.7 mg) and FTAE3B (20-40, $450.6 \mathrm{mg})$. Similar purification methods applied to FTAE3A afforded rhetsinine $(8 ; 1.1 \mathrm{mg})$ and soyauxinine (1; $3.1 \mathrm{mg})$, while sub-fraction FTAE3B gave soyauxinium nitrate (5; $30.8 \mathrm{mg})$.

\subsection{X-ray Diffraction Analyses}

All XRD data of compounds 1, 2, 3, 4, 4a, and 5 were collected on a SuperNova diffractometer (Rigaku, Tokyo, Japan ). Using Olex2 [18], the structures were solved and refined with the ShelX program package [19] using direct methods and least-squares minimization. The crystal of soyauxinine (1) was pseudo-merohedrically twinned; the second domain was rotated by $180^{\circ}$ around 100 (reciprocal) with a ratio 66:34. Both domains were taken into account for data reduction and refinement. The asymmetric unit of edulinine (3) contains two molecules with the same chirality $S$ at C14 resp. C35A/B, the Flack parameter refines to $0.06(6)$. The second molecule shows a disorder with a ratio 57:43 from C34 to C40. Except in this structure, the hydrogen atoms have been refined isotropically. CCDC 2039617 (1), 2039618 (2), 2069085 (3), 2039619 (4), 2069087 (4a) and 2069086 (5) contain the supplementary crystallographic data for this paper. This data is freely available at the Cambridge Crystallographic Data Centre via www.ccdc.cam.ac.uk/ conts/retrieving.html (accessed on 20 November 2021).

\subsection{Cytotoxic Activity of the Extract, Fractions, Isolates, and Semi-Synthetic Derivatives}

The cytotoxicity assay of some isolated compounds was performed on human cervix carcinoma (KB-3-1) cancer cell lines using the previously reported method [20]. The KB-3-1 cells were cultivated as a monolayer in Dulbecco's modified Eagle medium (DMEM) with glucose $(4.5 \mathrm{~g} / \mathrm{L})$, L-glutamine, sodium pyruvate and phenol red, supplemented with $10 \%$ (KB-3-1) foetal bovine serum (FBS). On the day before the test, the cells (70\% confluence) were detached with trypsin-ethylenediamine tetraacetic acid (EDTA) solution $(0.05 \% ; 0.02 \%$ in DPBS) and placed in sterile 96-well plates in a density of 10000 cells in $100 \mu \mathrm{L}$ medium per well. The dilution series of the compounds were prepared from stock solutions in DMSO with concentrations of $1 \mathrm{mM}$ or $10 \mathrm{mM}$. The stock solutions were diluted with culture medium (10\% FBS [KB-3-1]) at least 50 times. Some culture medium was added to the wells to adjust the volume of the wells to the required dilution factor. The dilution prepared from stock solution was added to the wells, and each concentration was tested in six replicates. The control contained the same concentration of DMSO as the first dilution. After incubation at $37{ }^{\circ} \mathrm{C}$ and $5.3 \% \mathrm{CO}_{2}$-humidified air for $72 \mathrm{~h}, 30 \mu \mathrm{L}$ of an aqueous resazurin solution $(175 \mu \mathrm{M})$ was added to each well. The cells were incubated for $6 \mathrm{~h}$ at the same conditions. Thereafter, the fluorescence was measured. The excitation was affected at a wavelength of $530 \mathrm{~nm}$, whereas the emission was recorded at $588 \mathrm{~nm}$. The $\mathrm{IC}_{50}$ were recorded as the values equal to the drug concentrations, at which vitality was $50 \%$, and was calculated as a sigmoidal dose-response curve using GraphPad Prism 4.03.

\subsection{Preparation of the Semis-Ynthetic Derivatives}

\subsubsection{Allylation of Edulinine}

Edulinine $(3,15.0 \mathrm{mg}, 0.051 \mathrm{mmol})$ was dissolved in dimethylformamide $(300 \mu \mathrm{L})$, and sodium hydride $(12.5 \mathrm{mg}, 0.313 \mathrm{mmol})$ was added to the medium. After complete dissolution, allyl bromide $(11.5 \mu \mathrm{L}, 0.133 \mathrm{mmol})$ was added and stirred at room temperature for $16 \mathrm{hrs}$. The reaction progress was monitored with LC-MS, and after the complete conversion of starting material, the reaction was quenched with water. Then, the organic layer was washed with brine water and reduced to dryness using a rotary evaporator. $2^{\prime}, 3^{\prime}$-diallyledulinine (3a, $2.4 \mathrm{mg}, 14.2 \%)$ and $N$-methylflindersine (3c, $2.1 \mathrm{mg}, 13 \%)$ were obtained. 
2, 3-Diallyledulinine (3a): Yellowish oil; ${ }^{1} \mathrm{H}-\mathrm{NMR}\left(500 \mathrm{MHz}, \mathrm{CD}_{3} \mathrm{OD}\right): \delta_{\mathrm{H}}$ (mult, J in Hertz) 7.88 (dd, $J=8.0,1.4$ Hz, H-4), 7.63 (ddd, $J=8.4,6.9,1.5 \mathrm{~Hz}, \mathrm{H}-6), 7.59$ (dd, $J=8.6$, $1.1 \mathrm{~Hz}, \mathrm{H}-7), 7.34$ (ddd, $J=8.1,6.9,1.2 \mathrm{~Hz}, \mathrm{H}-5), 5.86\left(\mathrm{ddt}, J=17.2,10.4,5.2 \mathrm{~Hz}, \mathrm{H}-2^{\prime}\right), 5.54$ $\left(\mathrm{ddt}, J=17.3,10.4,5.7 \mathrm{~Hz}, \mathrm{H}-5^{\prime}\right), 5.22\left(\mathrm{dq}, J=17.2,1.9 \mathrm{~Hz}, \mathrm{H}-3^{\prime}\right), 5.01(\mathrm{dq}, J=10.5,1.7 \mathrm{~Hz}$, H-3 $\left.{ }^{\prime}\right), 4.94\left(\mathrm{dq}, J=17.2,1.7 \mathrm{~Hz}, \mathrm{H}-3^{\prime}\right), 4.81\left(\mathrm{ddt}, J=10.4,2.3,1.3 \mathrm{~Hz}, \mathrm{H}-3^{\prime}\right), 4.06(\mathrm{ddt}, J=7.0$, 5.3, $\left.1.7 \mathrm{~Hz}, \mathrm{H}-1^{\prime}\right), 4.00\left(\mathrm{~s}, 3-\mathrm{OCH}_{3}\right), 3.92\left(\mathrm{~m}, \mathrm{H}-1^{\prime}\right), 3.74\left(\mathrm{~s}, \mathrm{NCH}_{3}\right), 3.35\left(\mathrm{~s}, \mathrm{H}-2^{\prime \prime}\right), 3.03(\mathrm{dd}$, $\left.J=13.4,9.8 \mathrm{~Hz}, \mathrm{H}-1^{\prime \prime}\right), 2.82\left(\mathrm{dd}, J=13.4,3.7 \mathrm{~Hz}, \mathrm{H}-1^{\prime \prime}\right), 1.30\left(\mathrm{~s}, \mathrm{H}-4^{\prime \prime}\right), 1.30\left(\mathrm{~s}, \mathrm{H}-5^{\prime \prime}\right) ;{ }^{13} \mathrm{C}-$ NMR (125 MHz, CD 3 OD): $\delta_{\mathrm{C}} 165.8$ (C-1), 163.4 (C-3), 140.2 (C-7a), 137.4(C-2'), 136.4(C-2'), 131.6 (C-6), 124.5 (C-5), 123.5 (C-4), 121.8 (C-2), 119.0 (C-3a), 116.3 (C-3'), 115.8(C-7), 115.4, $83.3\left(\mathrm{C}-3^{\prime \prime}\right), 79.4\left(\mathrm{C}-2^{\prime \prime}\right), 64.1\left(\mathrm{C}-1^{\prime}\right), 62.8\left(\mathrm{C}-1^{\prime}\right), 30.3\left(\mathrm{NC}_{3}\right), 21.8\left(\mathrm{C}-4^{\prime \prime}\right), 23.4\left(\mathrm{C}-5^{\prime \prime}\right), 21.8$ $\left(\mathrm{C}-5^{\prime \prime}\right)$; HRESIMS $[\mathrm{M}+\mathrm{Na}]^{+}$at $m / z 394.1978$ (calcd. $m / z 394.1988157$ for $\mathrm{C}_{22} \mathrm{H}_{29} \mathrm{NO}_{4} \mathrm{Na}$ ).

$N$-Methylflindersine (3c): Yellowish oil; ${ }^{1} \mathrm{H}-\mathrm{NMR}\left(500 \mathrm{MHz}, \mathrm{CDCl}_{3}\right) ; \delta 7.96(\mathrm{dd}, \mathrm{J}=8.0$, $1.6 \mathrm{~Hz}, \mathrm{H}-4), 7.32$ (m, H-5), 7.54 (ddd, $J=8.6,7.1,1.6 \mathrm{~Hz}, \mathrm{H}-6), 7.23$ (ddd, $J=8.1,7.1$, $1.0 \mathrm{~Hz}, \mathrm{H}-7), 6.75\left(\mathrm{~d}, J=9.9 \mathrm{~Hz}, \mathrm{H}-2^{\prime}\right), 5.53\left(\mathrm{~d}, J=9.9 \mathrm{~Hz}, \mathrm{H}-3^{\prime}\right), 3.69\left(\mathrm{~s}, \mathrm{NCH}_{3}\right), 1.51(\mathrm{~s}, 6 \mathrm{H})$; ${ }^{13} \mathrm{C}-\mathrm{NMR}\left(125 \mathrm{MHz}, \mathrm{CDCl}_{3}\right)$ : $\delta_{\mathrm{C}} 161.1$ (C-1), 118.0 (C-2), 155.3 (C-3), 114.1 (C-3a), 123.2 (C-4), 126.4 (C-5), 130.9 (C-6), 116.2 (C-7), 139.4 (C-7a), $78.6\left(\mathrm{C}-1^{\prime}\right), 118.0\left(\mathrm{C}-2^{\prime}\right), 126.4\left(\mathrm{C}-3^{\prime}\right)$, 115.4, $28.3\left(\mathrm{C}-4^{\prime}\right), 29.3\left(\mathrm{NCH}_{3}\right)$; HRESIMS [M + Na] ${ }^{+}$at $m / z 264.0999$ (calcd. $m / z 264.0995$ for $\left.\mathrm{C}_{15} \mathrm{H}_{15} \mathrm{NO}_{2} \mathrm{Na}\right)$.

\subsubsection{Acetonidation of Edulinine}

Edulinine (3, 26.2. $\mathrm{mg}, 0.090 \mathrm{mmol})$ was dissolved in acetone $(3.0 \mathrm{~mL})$, and a catalytic amount of $p$-toluene sulfonic acid $(23.3 \mathrm{mg}, 0.135 \mathrm{mmol})$ was added to the reaction mixture and was allowed to stir for four hours at room temperature. The reaction progress was monitored with LC-MS, and after the complete conversion of starting the material, the reaction was quenched with water. The reaction mixture was dissolved in water and extracted with chloroform. The organic layer was washed with brine water and reduced to dryness using a rotary evaporator. Edulinine-2' $3^{\prime}$-acetonide ( $3 \mathrm{~b}, 10.2 \mathrm{mg}, 34 \%$ ) was thus obtained. Yellow oil; ${ }^{1} \mathrm{H}-\mathrm{NMR}(500 \mathrm{MHz}, \mathrm{CDCl} 3): \delta_{\mathrm{H}}$ (mult, $J$ in Hertz) 7.85 (dd, $J=8.0$, $1.6 \mathrm{~Hz}, \mathrm{H}-4), 7.55$ (ddd, $J=8.6,7.1,1.6 \mathrm{~Hz}, \mathrm{H}-6), 7.38$ (dd, $J=8.6,0.9 \mathrm{~Hz}, \mathrm{H}-7), 7.27$ (m, H-5), $4.27\left(\mathrm{dd}, J=9.4,3.0 \mathrm{~Hz}, \mathrm{H}-1^{\prime}\right), 3.03\left(\mathrm{dd}, J=13.3,9.4 \mathrm{~Hz}, \mathrm{H}-2^{\prime}\right), 2.70(\mathrm{dd}, J=13.3,3.0 \mathrm{~Hz}$, $\left.\mathrm{H}-1^{\prime}\right), 4.04\left(\mathrm{~s}, 3-\mathrm{OCH}_{3}\right), 3.73\left(\mathrm{~s}, \mathrm{NCH}_{3}\right), 1.36\left(\mathrm{~s}, 4^{\prime}-\mathrm{CH}_{3}\right), 1.40\left(\mathrm{~s}, 5^{\prime}-\mathrm{CH}_{3}\right), 1.25\left(\mathrm{~s}, 4^{\prime}-\mathrm{CH}_{3}\right) 1.26$ $\left(\mathrm{s}, 5^{\prime}-\mathrm{CH}_{3}\right) ;{ }^{13} \mathrm{C}-\mathrm{NMR}\left(125 \mathrm{MHz}, \mathrm{CDCl}_{3}\right): \delta_{\mathrm{C}} 163.9$ (C-1), 161.6 (C-3), 139.4 (C-7a), 130.4 (C-6), 123.8 (C-5), 122.0 (C-4), 119.9 (C-3a), 117.9 (C-2' $\left.{ }^{\prime \prime}\right), 114.3$ (C-7), 106.6 (C-2), 80.6 (C-3'), $80.4\left(\mathrm{C}-2^{\prime}\right), 62.6\left(3-\mathrm{OCH}_{3}\right), 29.7(\mathrm{NCH} 3), 28.7\left(1^{\prime \prime}-\mathrm{CH}_{3}\right), 27.0\left(3^{\prime \prime}-\mathrm{CH}_{3}\right), 26.0\left(5^{\prime}-\mathrm{CH}_{3}\right), 25.9$ $\left(4^{\prime}-\mathrm{CH}_{3}\right), 23.2\left(1^{\prime}-\mathrm{CH} 2\right) ; \mathrm{HRESIMS}[\mathrm{M}+\mathrm{Na}]^{+}$at $m / z 354.1681$ (calcd. $m / z 354.1675$ for $\left.\mathrm{C}_{19} \mathrm{H}_{25} \mathrm{NO}_{4} \mathrm{Na}\right)$.

\subsubsection{Allylation of Ribalinine}

Ribalinine $(4,10.0 \mathrm{mg}, 0.038 \mathrm{mmol})$ was dissolved in dimethylformamide $(300 \mu \mathrm{L})$, and sodium hydride $(6.6 \mathrm{mg}, 0.165 \mathrm{mmol})$ was added to the medium. After complete dissolution, allyl bromide $(4.3 \mu \mathrm{L}, 0.050 \mathrm{mmol})$ was added and stirred at room temperature for $16 \mathrm{~h}$. The reaction progress was monitored with LC-MS, and after the complete conversion of the starting material, the reaction was quenched with water and reduced to dryness on a lyophilisator, and 2-allylribalinine $(4 \mathbf{b}, 6.2 \mathrm{mg}, 55 \%)$ was thus obtained. Yellow oil; ${ }^{1} \mathrm{H}-\mathrm{NMR}$ (500 MHz, CD $\left.{ }_{3} \mathrm{OD}\right): \delta_{\mathrm{H}}$ (mult, $J$ in Hertz) 7.86 (dd, $\left.J=8.1,1.6 \mathrm{~Hz}, \mathrm{H}-1\right), 7.23$ (ddd, $J=8.6$, 7.0, 1.6 Hz, H-3), 7.12 (m, H-4), 6.91 (ddd, $J=8.0,6.9,1.0 \mathrm{~Hz}, \mathrm{H}-2), 5.44$ (m, H-2'), 4.82 (dq, $\left.J=17.2,1.6 \mathrm{~Hz}, \mathrm{H}-3^{\prime}\right), 4.72\left(\mathrm{dq}, J=10.4,1.4 \mathrm{~Hz}, \mathrm{H}-3^{\prime}\right), 3.58(\mathrm{ddt}, J=12.8,6.1,1.4 \mathrm{~Hz}, \mathrm{H}-6)$, $3.17\left(\mathrm{t}, J=5.4 \mathrm{~Hz}, \mathrm{H}-1^{\prime}\right), 2.46(\mathrm{dd}, J=16.7,4.9 \mathrm{~Hz}, \mathrm{H}-7), 2.33(\mathrm{dd}, J=16.7,5.8 \mathrm{~Hz}, \mathrm{H}-7), 1.02$ $\left(\mathrm{d}, J=5.1 \mathrm{~Hz}, 1^{\prime}-\mathrm{CH}_{3}\right) ; 1.02\left(\mathrm{~d}, J=5.1 \mathrm{~Hz}, 1^{\prime}-\mathrm{CH}_{3}\right) ;{ }^{13} \mathrm{C}-\mathrm{NMR}\left(125 \mathrm{MHz}, \mathrm{CD}_{3} \mathrm{OD}\right): \delta_{\mathrm{C}} 178.0$ (C-8), 156.2 (C-5a), 139.8 (C-4a),135.3 (C-3),132.8 (C-2'),126.3 (C-8a), 124.1 (C-1), 123.8 (C-2), $117.7\left(\mathrm{C}-3^{\prime}\right), 115.9$ (C-4), 97.7 (C-7a), 83.2 (C-5), 75.6 (C-6), $71.3\left(\mathrm{C}-1^{\prime}\right), 31.0\left(\mathrm{NCH}_{3}\right), 25.6$ (C-7), $22.6\left(\mathrm{C}-2^{\prime \prime}\right), 22.4\left(\mathrm{C}-1^{\prime \prime}\right)$; HRESIMS [M + Na] ${ }^{+}$at $m / z 322.1407$ (calcd. $m / z 322.1413$ for $\mathrm{C}_{18} \mathrm{H}_{21} \mathrm{NO}_{3} \mathrm{Na}$ ) 


\subsubsection{Allylation of Soyauxinium Nitrate}

Soyauxinium nitrate $(5,20.4 \mathrm{mg}, 0.051 \mathrm{mmol})$ was dissolved in dimethylformamide $(300 \mu \mathrm{L})$ and sodium hydride $(6.2 \mathrm{mg}, 0.259 \mathrm{mmol})$ was added to the medium. After complete dissolution, allyl bromide $(13.4 \mu \mathrm{L}, 0.155 \mathrm{mmol})$ was added and stirred at room temperature for $16 \mathrm{hrs}$. The reaction progress was monitored with LC-MS, and after the complete conversion of the starting material, the reaction was quenched with water and reduced to dryness on a lyophilisator. $\mathrm{N}$-allylsoyauxinine $(5 \mathrm{a}, 10.2 \mathrm{mg}, 52 \%)$ was obtained. Yellow oil; ${ }^{1} \mathrm{H}-\mathrm{NMR}\left(600 \mathrm{MHz}, \mathrm{CDCl}_{3}\right) ; \delta_{\mathrm{H}}$ (mult, $J$ in Hertz) $7.78(\mathrm{brs}, 1-\mathrm{HN}), 7.66(\mathrm{dt}$, $J=8.1,1.1 \mathrm{~Hz}, \mathrm{H}-9), 7.42$ (m, H-5), 7.38 (m, H-10), 7.19 (m, H-12), 6.12 (d, J = 6.0 Hz, H-4), $6.12(\mathrm{~d}, J=6.0 \mathrm{~Hz}, \mathrm{H}-2), 5.94\left(\mathrm{ddt}, J=17.1,10.4,5.2 \mathrm{~Hz}, \mathrm{H}-2^{\prime}\right), 5.22\left(\mathrm{~m}, \mathrm{H}-1^{\prime}\right), 5.06(\mathrm{dq}$, $\left.J=10.2,1.4 \mathrm{~Hz}, \mathrm{H}-3^{\prime}\right), 4.92\left(\mathrm{dq}, J=17.1,1.6 \mathrm{~Hz}, \mathrm{H}-3^{\prime}\right) .4 .11(\mathrm{t}, J=6.4 \mathrm{~Hz}, \mathrm{H}-7), 3.20(\mathrm{t}$, $J=6.4 \mathrm{~Hz}, \mathrm{H}-8), 2.92\left(\mathrm{~d}, J=4.0,1-\mathrm{NH}_{3}\right), 3.84\left(\mathrm{~s}, 3-\mathrm{OCH}_{3}\right) ;{ }^{13} \mathrm{C}-\mathrm{NMR}\left(125 \mathrm{MHz}, \mathrm{CDCl}_{3}\right)$ : $\delta_{\mathrm{C}}$ 94.7(C-2), 102.4 (C-4), 108.9 (C-5a), 111.0 (C-12), 116.2 (C-3'), 120.7 (C-9), 120.9 (C-10), 123.1 (C-8a), 124.1(C-2'), 125.2 (C-9a), 126.1 (C-11), 134.0(C-13a), 135.3 (C-5), 139.6 (C-12a), 153.9 (C-1), 162.2 (C-13), 165.2 (C-3), 175.6 (C-6), $55.2\left(3-\mathrm{OCH}_{3}\right), 47.4\left(\mathrm{C}-1^{\prime}\right), 46.8$ (C-7), $29.7\left(1-\mathrm{NCH}_{3}\right), 21.4(\mathrm{C}-8)$; HRESIMS [M + Na] ${ }^{+}$at $m / z 412.1629$ (calcd. $m / z 412.1631$ for $\mathrm{C}_{23} \mathrm{H}_{23} \mathrm{~N}_{3} \mathrm{O}_{3} \mathrm{Na}$ ).

\subsubsection{Allylation of Arborinine}

Arborinine $(6,2.7 \mathrm{mg}, 0.0095 \mathrm{mmol})$ was dissolved in dimethylformamide $(300 \mu \mathrm{L})$, and potassium carbonate $(2.5 \mu \mathrm{L}, 0.047 \mathrm{mmol})$ was added to the medium. After complete dissolution, allyl bromide $(3.4 \mathrm{mg}, 0.028 \mathrm{mmol})$ was added and stirred at room temperature for $16 \mathrm{~h}$. The reaction progress was monitored with LC-MS, and after the complete conversion of the starting material, the reaction was quenched with water and reduced to dryness on a lyophilisator. The reaction afforded 1-allylarborinine $(\mathbf{6 a}, 1.1 \mathrm{mg}, 37 \%)$. Yellow oil; ${ }^{1} \mathrm{H}-\mathrm{NMR}\left(500 \mathrm{MHz} ; \mathrm{CDCl}_{3}\right): \delta_{\mathrm{H}}$ (mult, $J$ in Hertz) $8.49(\mathrm{dd}, J=8.0,1.7 \mathrm{~Hz}, \mathrm{H}-8)$, 7.65 (ddd, $J=8.6,6.9,1.7 \mathrm{~Hz}, \mathrm{H}-6), 7.44$ (d, $J=8.6 \mathrm{~Hz}, \mathrm{H}-5), 7.24$ (m, H-7), 6.62 (s, H-4), $6.29\left(\mathrm{ddt}, J=16.7,10.3,6.0 \mathrm{~Hz}, \mathrm{H}-2^{\prime}\right), 5.41\left(\mathrm{dq}, J=17.2,1.6 \mathrm{~Hz}, \mathrm{H}-3^{\prime}\right), 5.22(\mathrm{dq}, J=10.4$, $\left.1.3 \mathrm{~Hz}, \mathrm{H}-3^{\prime}\right), 4.69\left(\mathrm{dt}, J=6.0,1.4 \mathrm{~Hz}, \mathrm{H}-\mathrm{1}^{\prime}\right), 4.02\left(\mathrm{~s}, 3-\mathrm{OCH}_{3}\right), 3.90\left(\mathrm{~s}, 2-\mathrm{OCH}_{3}\right), 3.36(\mathrm{~s}, 3 \mathrm{H})$; ${ }^{13} \mathrm{C}-\mathrm{NMR}\left(125 \mathrm{MHz}, \mathrm{CDCl}_{3}\right): \delta_{\mathrm{C}} 177.6(\mathrm{C}-9), 158.5(\mathrm{C}-2), 153.1$ (C-1), 142.5 (C-4a), 142.3(C-5), 138.4(C-3), 133.7(C-6), 127.4(C-8), 123.7(C-8a), 121.8(C-7), 118.1(C-3'),115.1(C-5a), 112.2(C9a), 93.5(C-4), 76.0(C-1'), 61.6(2-OCLH $\left.\mathrm{H}_{3}\right), 56.3\left(3-\mathrm{OCH}_{3}\right), 35.1\left(\mathrm{NC}_{3}\right)$; HRESIMS $\left([\mathrm{M}+\mathrm{Na}]^{+}\right)$ at $m / z 348.1200$ (calcd. $m / z 348.1206$ for $\mathrm{C}_{19} \mathrm{H}_{19} \mathrm{NO}_{4} \mathrm{Na}$ ).

\section{Conclusions}

A completely different chemical profile of Araliopsis soyauxii was evidenced after the chemical analysis of the total alkaloid extract of its stem bark compared to previous reports on the same plant, with the isolation of ten alkaloids, including a new indolopyridoquinazoline alkaloid. This will contribute to the enrichment of the databases of organic compounds from Nature. SC-XRD was used as a powerful tool to determine the absolute and conformational stereochemistry of alkaloids and their counterions. The technique allowed us to carry out a structural revision of the previously described soyauxinium chloride to soyauxinium nitrate. The evaluation of the cytotoxic activity of $A$. soyauxii alkaloids revealed the isolated compounds to be almost inactive, except for maculine, which showed moderate activity against the KB-3-1 cancer cell line. The inactivity of the semi-synthetic derivatives after allylation and acetonidation reactions allowed us to conclude that increasing the lipophilicity of these compounds alone is insufficient to enhance their cytotoxic activity and the moderate activity of arborinine and soyauxinium nitrate might be related to their free hydroxyl and amine groups, respectively.

Supplementary Materials: The following supporting information can be downloaded. Figure S1: ESI-HR Mass spectrum of 1, Figure S2-S7: 1 and 2D NMR spectra of 1, Figure S8: ESI-HR Mass spectrum of 3a, Figure S9-S12: ${ }^{1} \mathrm{H}$ and ${ }^{13} \mathrm{C}-\mathrm{NMR}$ spectra of 3a, Figure S13: ESI-HR Mass spectrum of $\mathbf{3} \mathbf{b}$, Figure S14-S15: ${ }^{1} \mathrm{H}$ and ${ }^{13} \mathrm{C}-\mathrm{NMR}$ spectra of $\mathbf{3} \mathbf{b}$, Figure S16: ESI-HR Mass spectrum 
of 3c, Figure S17-S18: ${ }^{1} \mathrm{H}$ and ${ }^{13} \mathrm{C}-\mathrm{NMR}$ spectra of 3c, Figure S19: ESI-HR Mass spectrum of $4 \mathbf{b}$, Figure S20-S21: ${ }^{1} \mathrm{H}$ and ${ }^{13} \mathrm{C}-\mathrm{NMR}$ spectra of $\mathbf{4 b}$, Figure S22: ESI Mass spectrum of 5a, Figure S23: ${ }^{1} \mathrm{H}-\mathrm{NMR}$ spectrum of 5a, Figure S24: ESI-HR Mass spectrum of 5a, Figure S25: ESI-HR Mass spectrum of $6 \mathbf{a}$, Figure S26-S27: ${ }^{1} \mathrm{H}$ and ${ }^{13} \mathrm{C}-\mathrm{NMR}$ spectra of $\mathbf{6 a}$, Figure S28: Mass spectrum of 5, Figure S29: ${ }^{1} \mathrm{H}$ spectrum of 5, Figure S30: Mass spectrum of soyauxinium chloride, Figure S31-S35: 1 and 2D NMR spectra of soyauxinium chloride.

Author Contributions: Conceptualization, E.N.H. and B.T.N.; Formal analysis, C.G.T.N. and G.T.B.M.; Funding acquisition, B.N.L. and N.S.; Investigation, C.G.T.N. and H.-G.S.; Methodology, C.G.T.N., A.F.A. and G.T.B.M.; Project administration, B.N.L.; Supervision, E.N.H. and B.T.N.; Validation, G.W.F.and B.N.L.; Writing-original draft, C.G.T.N., J.L.N.O., G.T.B.M., G.W.F. and H.-G.S.; Writingreview \& editing, G.W.F., B.N.L. and N.S. All authors have read and agreed to the published version of the manuscript.

Funding: The project was funded by DAAD (German Academic Exchange Service, project ID 57316173) in the frame of the Yaoundé-Bielefeld Graduate School of Natural Products with Antiparasite and Antibacterial Activities (YaBiNaPA, www.yabinapa.de (accessed on 20 November 2021)). Coverage of the publication costs by the Open Access Publication Fund of Bielefeld University is gratefully acknowledged.

Institutional Review Board Statement: Not applicable.

Informed Consent Statement: Not applicable.

Data Availability Statement: Not applicable.

Acknowledgments: The NMR and mass spectrometry service units at Bielefeld University are gratefully acknowledged.

Conflicts of Interest: The authors declare no conflict of interest.

Sample Availability: Samples of the compounds are not available from the authors.

\section{References}

1. Noulala, T.C.G.; Fotso, W.G.; Rennert, R.; Lenta, N.B.; Sewald, N.; Arnold, N.; Happi, N.E.; Ngadjui, T.B. Mesomeric form of quaternary indoloquinazoline alkaloid and other constituents from the Cameroonian Rutaceae Araliopsis soyauxii Engl. Biochem. Syst. Ecol. 2020, 91, 104050. [CrossRef]

2. Mbaveng, A.T.; Noulala, T.G.C.; Samba, R.M.A.; Tankeo, B.S.; Abdelfatah, S.; Fotso, W.G.; Happi, N.E.; Ngadjui, T.B.; Beng, P.V.; Kuete, V.; et al. The alkaloid, soyauxinium chloride, displays remarkable cytotoxic effects towards a panel of cancer cells, inducing apoptosis, ferroptosis and necroptosis. Chem. Biol. Interact. 2020, 333, 109334. [CrossRef]

3. Mbaveng, A.T.; Noulala, T.G.C.; Samba, R.M.A.; Tankeo, B.S.; Fotso, W.G.; Happi, N.E.; Ngadjui, T.B.; Beng, P.V.; Kuete, V.; Efferth, T. Cytotoxicity of botanicals and isolated phytochemicals from Araliopsis soyauxii Engl. (Rutaceae) towards a panel of human cancer cells. J. Ethnopharmacol. 2020, 267, 113535. [CrossRef]

4. Chaturvedula, P.V.S.; Schilling, J.K.; Miller, J.S.; Andriantsiferana, R.; Rasamison, V.E.; Kingston, D.G.I. New cytotoxic alkaloids from the wood of Vepris punctata from the Madagascar Rainforest. J. Nat. Prod. 2003, 66, 532-534. [CrossRef] [PubMed]

5. Chaturvedula, P.V.S.; Schilling, J.K.; Miller, J.S.; Andriantsiferana, R.; Rasamison, V.E.; Kingston, D.G.I. New cytotoxic terpenoids from the wood of Vepris punctata from the Madagascar Rainforest. J. Nat. Prod. 2004, 67, 895-898. [CrossRef] [PubMed]

6. Kouam, K.A.D.; Kenmogne, S.B.; Lobe, J.S.; Happi, N.E.; Stammler, H.-G.; Waffo, K.F.A.; Sewald, N.; Wansi, J.D. A rotameric tryptamide alkaloid from the roots of Vepris lecomteana (Pierre) Cheek \& T. Heller (Rutaceae). Fitoterapia 2019, 135, 9-14.

7. Kouam, K.A.D.; Bissoue, N.A.; Tcho, T.A.; Happi, N.E.; Waffo, K.F.A.; Sewald, N.; Wansi, J.D. Antimicrobial Furoquinoline Alkaloids from Vepris lecomteana (Pierre) Cheek \& T. Heller (Rutaceae). Molecules 2018, 23, 13.

8. Wang, Q.; Liang, J.; Feng, X. X-ray crystallographic analysis and revision of nmr spectral assignments for rhetsinine. J. China Pharm. 2009, 40, 503-505.

9. Christopher, E.; Bedira, E.; Dunbar, C.; Khan, I.A.; Okunji, C.O.; Schuster, B.M.; Iwu, M.M. Indoloquinazoline alkaloids from Araliopsis tabouensis. Helv. Chim. Acta 2003, 86, 2914-2918. [CrossRef]

10. Wabo, H.K.; Tane, P.; Connolly, J.D.; Okunji, C.C.; Schuster, B.M.; Iwu, M. Tabouensinium chloride, a novel quaternary pyranoquinoline alkaloid from Araliopsis tabouensis. Nat. Prod. Res. 2005, 6, 591-595. [CrossRef] [PubMed]

11. Umar, S.; Iqbal, M. Nitrate accumulation in plants, factors affecting the process, and human health implications. A review. Agron. Sustain. Dev. 2007, 27, 45-57.

12. Barron, D.; Balland, C.; Possety, F.; Ravanel, P.; Desfougères, A. Flavonoïdes prénylés et perméabilité membranaire. Acta Bot. Gall. 1996, 143, 509-520. [CrossRef] 
13. Tameye, J.S.N.; Akak, M.C.; Happi, M.G.; Frese, M.; Stammler, H.-G.; Neumann, B.; Lenta, N.B.; Sewald, N.; Nkengfack, E.A. Antioxidant norbergenin derivatives from the leaves of Diospyros gilletii De Wild (Ebenaceae). Phytochem. Lett. 2020, 36, 63-67. [CrossRef]

14. Tabekoueng, B.G.; Akak, M.C.; Happi, G.M.; Langat, M.K.; Frese, M.; Stammler, H.-G.; Neumann, B.; Azebaze, A.G.B.; Waffo, A.F.; Wansi, J.D.; et al. The chemistry of the West and Central African Penianthus zenkeri Diels (Menispermaceae). Phytochem. Lett. 2020, 38, 12-18. [CrossRef]

15. Happi, G.M.; Kemayou, G.P.M.; Stammler, H.-G.; Neumann, B.; Ismael, M.; Kouam, S.F.; Wansi, J.D.; Tchouankeu, J.C.; Frese, M.; Lenta, N.B.; et al. Three phragmalin-type limonoids orthoesters and the structure of odoratone isolated from the bark of Entandrophragma candollei (Meliaceae). Phytochemistry 2021, 181, 112537. [CrossRef] [PubMed]

16. Tsopgni, T.W.D.; Azebaze, A.G.B.; Teinkela, M.J.E.; Lenta, N.B.; Bosyom, F.F.; Ngadjui, T.B.; Vardamides, J.C. New unsaturated fatty acid and other chemical constituents from the roots of Cola rostrata K. Schum. (Malvaceae). Biochem. Syst. Ecol. 2019, 86, 103913. [CrossRef]

17. Réthy, B.; Zupkó, I.; Minorics, R.; Hohmann, J.; Ocsovszki, I.; Falkay, G. Investigation of cytotoxic activity on human cancer cell lines of arborinine and furanoacridones isolated from Ruta graveolens. Planta Med. 2007, 73, 41-48. [CrossRef] [PubMed]

18. Dolomanov, O.V.; Bourhis, L.J.; Gildea, R.J.; Howard, J.A.K.; Puschmann, H.J. OLEX2: A complete structure solution, refinement and analysis program. J. Appl. Cryst. 2009, 42, 339-341. [CrossRef]

19. Sheldrick, G.M. A short history of SHELX. Acta Cryst. 2008, A64, 112-122. [CrossRef] [PubMed]

20. Sammet, B.; Bogner, T.; Nahrwold, M.; Weiss, C.; Sewald, N. Approaches for the synthesis of functionalized cryptophycins. J. Org. Chem. 2010, 75, 6953-6960. [CrossRef] [PubMed] 